\title{
IMPLEMENTASI THEORY OF PLANNED BEHAVIOR DAN RISK TOLERANCE TERHADAP INTENSI INVESTASI PEER TO PEER LENDING
}

\author{
Siti Mauidhoh Syarfi \\ Universitas Negeri Surabaya \\ sitisyarfi16080574090@mhs.unesa.ac.id \\ Nadia Asandimitra \\ Universitas Negeri Surabaya \\ nadiaharyono@unesa.ac.id
}

\begin{abstract}
The purpose of this study is to determine the effect of attitude toward behavior, subjective norm, perceived behavioral control, and risk tolerance on investment intention of Surabayanese in peer to peer lending. This study is conclusive causality research with quantitative research data using a purposive sampling method and a random sampling method to get samples. Data in this study obtained by a questionnaire with a Likert scale. The sample used in this study were 200 Surabaya's workforce. The analysis method used is multiple linear regression analysis using the SPSS program. The result is based on hypothesis testing that shows that attitude toward behavior and risk tolerance significantly influences investment intention. While the subjective norm and perceived behavioral control do not affect investment intention. It is because of the distribution respondents that dominated by young people that have age between 18-25 years. The respondents have a low belief in their social relations. It was also caused by respondents who have less information about fintech P2P lending which come up in Indonesia in 2016 and classified as a new type of investment.
\end{abstract}

Keywords: attitude toward behavior; investment intention; perceived behavioral control; risk tolerance; subjective norm.

\section{PENDAHULUAN}

Berkembangnya gaya hidup masyarakat secara terus menerus yang menyebabkan meningkatnya kebutuhan sandang pangan mengharuskan masyarakat cermat mengelola dan menyimpan uang dengan baik untuk kebutuhan di masa mendatang (Annur, 2019). Salah satu cara untuk menyimpan uang dengan baik sekaligus terdapat harapan keuntungan akan diperoleh di waktu yang akan datang yaitu investasi (Deviyanti, Purnamawati, \& Yasa, 2017). Menurut Fahmi, (2012), investasi dibedakan menjadi 2 (dua) jenis investasi yakni investasi riil di mana investasi bisa terlihat secara fisik atau berwujud seperti emas, rumah, tanah, dan investasi keuangan atau financial yang merupakan investasi dalam bentuk yang tidak bisa dilihat secara fisik yang dimungkinkan pelaksanaanya pada pasar uang, pasar modal, pasar berjangka, maupun fintech.

Perkembangan gaya hidup dan perekonomian masyarakat juga tidak terlepas dari munculnya perkembangan inovasi teknologi keuangan (fintech) yang menyebabkan terbentuknya sistim bisnis dan keuangan baru. Adanya fintech mampu meningkatkan sistim keuangan dan juga membantu masyarakat unbanked melakukan berbagai transaksi keuangan dengan mudah.

Di Indonesia, ditemukan dari berbagai macam fintech yang ada, peer to peer lending menjadi fintech terpopuler dan tumbuh paling pesat pada akhir tahun 2018 menurut Menteri Koordinator Perekonomian Indonesia disusul oleh fintech pembayaran, analisa data pasar, urun dana, manajemen kekayaan, analitik dan AI, asuransi,dan lainnya (Jayani, 2019). P2P lending kerap disebut sebagai "Layanan Pinjam Meminjam Uang Berbasis Teknologi Informasi" oleh Otoritas Jasa Keuangan (OJK) sebagai regulator dari fintech di Indonesia. Peraturan mengenai P2P lending tertuang dalam POJK 77/POJK.01/2016 tentang Layanan Pinjam Meminjam Uang Berbasis Teknologi Informasi dan Beleid Nomor 13/POJK.02/2018 tentang Inovasi Keuangan Digital di Sektor Jasa Keuangan. Hingga Juni 2019, telah terdaftar 113 perusahaan $P 2 P$ lending pada OJK (OJK, 2019). Industri $P 2 P$ lending tersebut menyediakan wadah bagi para lender dan borrower tanpa menggunakan lembaga keuangan bank 
sebagai perantara. Untuk menjadi lender atau biasa disebut investor pada $P 2 P$ lending hanya diperlukan data pribadi dan memiliki dana dengan cara yang praktis yaitu melalui online.

Dari data statistik yang telah diungkapkan oleh OJK (2019) didapatkan bahwa hingga Februari 2019, akumulasi transaksi borrower meningkat dengan jumlah yang lebih besar dibandingkan jumlah investor. Di Pulau Jawa jumlah lender dan borrower yaitu 9.717.153 dan 16.673.197 akun. Daerah luar Pulau Jawa dengan jumlah lender dan borrower yaitu 667.404 dan 3.083.499 akun. Dan luar negeri yaitu dengan jumlah lender sebanyak 3.404.302 akun. Jumlah terbanyak yang didapatkan di Pulau Jawa di mana banyak berdiri Usaha Mikro Kecil dan Menengah (UMKM) selaku pihak peminjam dana pada $P 2 P$ lending. Dan didapatkan 7 perusahaan $P 2 P$ lending terpopuler menurut OJK yakni Danamas, Investree, Amartha, Dompet Kilat, KIMO, Toko Modal, dan Uang Teman.

Kontribusi UMKM terhadap PDB Indonesia sendiri sangat besar hingga pada tahun 2018 mencapai $60,34 \%$ dan diharapkan terus meningkat setiap tahunnya (Syarizka, 2019). Oleh sebab itu OJK melalui $P 2 P$ lending ingin mendukung dan mendorong kinerja UMKM melalui penyaluran pendanaan dengan mengeluarkan peraturan dengan mewajibkan para pelaku bisnis $P 2 P$ lending untuk menyalurkan dananya minimal 20\% kepada sektor produktif seperti UMKM. Hal tersebut dikarenakan mayoritas para startup UMKM banyak mengalami keterbatasan modal dan marketing (Walfajri, 2019). Dari Pulau Jawa, Jawa Timur menjadi provinsi dengan peningkatan jumlah UMKM yang sangat signifikan dengan pertumbuhan yang melesat. Kontribusi UMKM di Jawa Timur pada PDRB Jatim terus meningkat setiap tahun dan pada semester pertama tahun 2018 sebanyak Rp 95,95 triliun yang menandakan bahwa UMKM berperan besar pada pembangunan ekonomi Jawa Timur (JatimNewsroom, 2018).

Selaku Ibu Kota Jawa Timur dan kota terbesar di Jawa Timur, peningkatan jumlah UMKM Kota Surabaya pada berbagai sektor berada pada jumlah yang masih jauh di bawah kota lain seperti Kota Jember dan Kota Malang. Pada tahun 2018 jumlah UMKM di Kota Jember sebanyak 424.151, Kota Malang sebesar 414.516 dan Kota Surabaya sebanyak 260.762. Oleh sebab itu, Pemerintah Kota Surabaya terus berupaya mengembangkan potensi UMKM yang ada dengan meminta para UMKM untuk menjadi "Pahlawan Ekonomi" yang diharapkan menyumbang lebih banyak pada PDRB Jawa Timur (Jajeli, 2018). Hal tersebut sejalan dengan Kementrian Komunikasi dan Informatika yang juga mengajak UMKM Surabaya untuk terus berinovasi di bidang teknologi yang selaras dengan pencapaian Visi 2020 "The Digital Energy of Asia" (Kominfo, 2019). Untuk mewujudkan hal tersebut tentunya UMKM memerlukan adanya tambahan modal usaha yang bisa didapatkan melalui pinjaman produktif. Fenomena tersebut tepat bagi para investor di Kota Surabaya untuk berinvestasi pada $P 2 P$ lending yang menyediakan pinjaman modal produktif bagi para UMKM. Sehingga studi ini dimaksudkan untuk mengungkap lebih jauh mengenai faktor-faktor yang memengaruhi intensi investasi masyarakat Surabaya pada $P 2 P$ lending. Karena pada akhirnya, berinvestasi akan mendorong pertumbuhan ekonomi Indonesia secara lebih merata (Aristanti, 2019).

Berinvestasi bukan hanya membutuhkan modal berupa uang maupun aset, namun terdapat beragam faktor yang dapat berpengaruh pada keputusan sebelum melakukan investasi, saat berinvestasi, maupun setelah berinvestasi. Faktor tersebut yaitu faktor psikologi di mana banyak orang yang tidak menyadari pengaruhnya pada pengambilan keputusan saat berinvesatasi. Kecerdasan emosional investor dapat dilihat dari sikap investor dalam menentukan instrumen investasi dan cara mengelolanya. Namun selain instrumen investasi, preferensi investor juga berkaitan dengan menilai return dan risk. Batasan risiko yang sanggup diterima oleh tiap investor tentu beragam namun mereka berharap mendapatkan return yang sesuai. Untuk melakukan suatu tindakan investasi, hal pertama yang harus dimiliki oleh para investor yaitu minat/ intensi untuk berinvestasi. Sesuai dengan Theory of Planned Behavior (TPB) yang mengemukakan bahwa niat individu dalam berperilaku merupakan penentu langsung dari perilaku tersebut. Theory of Planned Behavior juga mengemukakan bahwa kecenderungan individu berperilaku adalah sesuai dengan minat/ intensi dan persepsi pengendalian melalui perilaku tertentu, dan tingkah laku, norma subjektif serta pengendalian perilaku merupakan faktor yang memngaruhi intensi investasi (Ajzen, 1991). 
Siti Mauidhoh Syarfi. Implementasi Theory of Planned Behavior dan Risk Tolerance terhadap Intensi Investasi Peer to Peer Lending

Dari fenomena yang telah dipaparkan, penulis berminat untuk mengeksplorasi lebih jauh mengenai beberapa faktor yang memengaruhi intensi masyarakat Surabaya untuk berinvestasi pada fintech $P 2 P$ lending berlandaskan Theory of Planned Behavior (TPB) sebab sesuai dengan Theory of Planned Behavior (TPB) yang mengemukakan bahwa niat individu dalam berperilaku merupakan penentu langsung dari perilaku tersebut dan risk tolerance sebab selain instrumen investasi, preferensi investor juga berkaitan dengan menilai return dan risk. Terdapat 3 elemen yang dapat melandasi tindakan individu berdasarkan TPB, antara lain attitude toward behavior, subjective norm, dan perceived behavioral control (Ajzen, 1991). Dari telaah beberapa hasil penelitian sebelumnya ditemukan perbedaan hasil penelitian mengenai pengaruh attitude toward behavior, subjective norm, dan perceived behavioral control, dan risk tolerance atas intensi investasi.

Attitude toward behavior ialah sikap terhadap perilaku yang ditentukan oleh beberapa kepercayaan (behavioral beliefs) individu yang berhubungan dengan evaluasi subjektif individu berkenaan pada lingkungan sekelilingnya. Pemahaman individu atas diri dan lingkungannya yang dilaksanakan melalui cara mengaitkan perilaku tertentu dengan bermacam keuntungan ataupun rugi yang bisa timbul dari pelaksanaan suatu perilaku tertentu. Attitude toward behavior berhubungan dengan emosi, afeksi dan kognisi kemudian menjadi evaluasi perasaan seseorang yang menempatkan pada keputusan menerima atau menolak investasi tersebut (Ajzen, 2005). Dalam Dewi, (2018); Seni \& Ratnadi, (2017); Sondari \& Sudarsono, (2015); Alleyne \& Broome, (2011); Raut, Das, \& Kumar, (2018); Phan \& Zhou, (2014); Rahmawati \& Maslichah, (2018); Luky, (2016); dan Taufiqoh, Diana, \& Junaidi, (2019) secara positif attitude toward behavior berpengaruh terhadap intensi investasi. Sedangkan dalam Dayaratne \& Wijethunga, (2015); Paramita, Isbanah, Kusumaningrum, Musdholifah, \& Hartono, (2018); dan Mahastanti \& Hariady, (2014) menjelaskan bahwa Attitude toward behavior tidak memengaruhi intensi investasi.

Subjective norm ialah persepsi individu terhadap perilaku tertentu dan bersumber dari anggapan orang lain terhadap perilaku tersebut. Pengaruh tersebut dapat berupa dorongan yang kuat atau persetujuan orang lain sehingga terbentuk niat atau intensi investasi (Ajzen, 2005). Dalam penelitian Seni \& Ratnadi, (2017); Sondari \& Sudarsono, (2015); Alleyne \& Broome, (2011); Dayaratne \& Wijethunga, (2015); Raut et al., (2018); Phan \& Zhou, (2014); dan Deviyanti, Purnamawati, \& Yasa, (2017) menyebutkan bahwa Subjective norm berpengaruh secara positif terhadap intensi investasi. Sedangkan penelitian Rahmawati \& Maslichah, (2018); Paramita et al., (2018); Mahastanti \& Hariady, (2014); dan Luky, (2016) menyatakan bahwa intensi investasi tidak dipengaruhi oleh Subjective norm.

Perceived behavioral control ialah persepsi individu terhadap sulit atau mudahnya untuk mewujudkan perilaku tertentu yang dapat diakibatkan oleh faktor eksternal maupun faktor internal. Kontrol perilaku akan memunculkan niat berinvestasi apabila seseorang memiliki persepsi untuk mampu menghilangkan halangan berinvestasi melalui faktor-faktor pendukung (Ajzen, 2005). Secara positif Perceived behavioral control berpengaruh terhadap intensi investasi (Tandio \& Widanaputra, 2016); (Seni \& Ratnadi, 2017); (Alleyne \& Broome, 2011); (Raut et al., 2018); (Phan \& Zhou, 2014); (Rahmawati \& Maslichah, 2018); dan (Mahastanti \& Hariady, 2014). Namun dalam penelitian Sondari \& Sudarsono, (2015); Dayaratne \& Wijethunga, (2015); Paramita et al., (2018); dan Luky, (2016), menyebutkan bahwa tidak ada pengaruh antara perceived behavioral control dan intensi investasi.

Putri, Hakim, \& Bramanti, (2017) mendeskripsikan risk tolerance sebagai jumlah umum ketidakpastian seseorang yang mampu diterima saat membuat keputusan financial yang hampir menyentuh setiap bagian dari aktivitas sosial dan ekonomi. Risiko ialah kemungkinan ketidaksamaan antara return aktual dan return yang diharapkan. Halim, (2005) mengungkapkan ada 3 jenis investor terkait dengan preferensinya yaitu 1) investor yang menyukai risiko (risk seeker), 2) investor yang netral terhadap risiko (risk neutral), dan 3) investor yang menghindari risiko (risk averse). Secara positif risk tolerance berpengaruh terhadap intensi investasi (Pradikasari \& Isbanah, 2018); (Alleyne \& Broome, 2011); (Hilaliyah, Susyanti, \& Wahono, 2019); (Budiarto \& Susanti, 2017); (Mahastanti \& Hariady, 2014); (Baghani \& Sedaghat, 2014); dan (Hikmah, Siagian, \& Siregar, 2020). Sedangkan dalam hasil penelitian Putra et al., (2016); dan Trenggana \& Kuswardhana, (2017) menuturkan bahwa risk tolerance tidak berpengaruh terhadap keputusan investasi. 
Penelitian ini bertujuan menganalisis pengaruh attitude toward behavior, subjective norm, perceived behavioral control, dan risk tolerance terhadap intensi investasi masyarakat Surabaya pada peer to peer lending.

\section{KAJIAN PUSTAKA DAN PENGEMBANGAN HIPOTESIS}

\section{Theory of Planned Behavior}

Theory of Planned Behavior (TPB) ialah teori yang dikemukakan oleh Ajzen, (1991) yang merupakan teori yang berkaitan dengan studi perilaku seseorang (Ajzen, 2002). Faktor utama dalam teori perilaku terencana untuk melaksanakan suatu perilaku tertentu yakni niat individu. Segala sesuatu yang dilakukan setiap individu memiliki maksud dan tujuan yang ingin dicapainya. Semakin besar niat dalam berperilaku, semakin besar kemungkinan kinerjanya. Niat individu dalam berperilaku didasari oleh tiga jenis pertimbangan yakni attitude toward behavior, subjective norm, dan perceived behavioral control (Ajzen, 1991).

Pada dasarnya di dalam teori ini dijelaskan bahwa manusia adalah makhluk rasional. Manusia bertingkah laku sesuai dengan pertimbangan akal sehat dengan mempertimbangkan dampak dari tingkah laku tersebut. Karena manusia merupakan makhluk sosial, maka mereka akan membutuhkan orang lain ketika menjalani kehidupan. Hal tersebut juga mengindikasikan bahwa perilaku yang diperlihatkan oleh sesorang juga akan memengaruhi orang lain (Ajzen, 1991).

\section{Prospect Theory}

Prospect theory ialah sebuah teori berkenaan dengan sikap manusia yang dihadapkan pada aktivitas yang hasilnya tidak menentu ketika mengambil suatu keputusan (Kahneman \& Tversky, 1992). Prospect theory menjelaskan sesungguhnya tindakan individu tidak selalu sesuai dengan standar teori keuangan mengenai risiko dan kepastian, terdapat faktor lain yang ditambahkan seseorang yakni faktor psikologi dan perilaku yang tidak menentu ketika dihadapkan pada pilihan rasional. Salah satu faktor yang menjadi penyebab hal tersebut yakni decison frame. Hal yang dikemukakan teori ini yakni beberapa karakter daripada investor ketika dihadapkan dengan risiko, yakni risk aversion dan loss aversion. Risk aversion merupakan perilaku dari seseorang yang cenderung ingin terhindar dari risiko namun tetap berharap pengembalian yang tinggi melebihi besarnya risiko yang dihadapi. Sedangkan loss aversion merupakan perilaku seseorang yang cenderung menghindari kerugian karena lebih takut akan kehilangan daripada mendapatkan kepuasan imbal hasil (Kahneman \& Tversky, 1992).

\section{Intensi Investasi}

Intensi merupakan posisi individu dalam dimensi probabilitas subjektif yang mengaitkan hubungan antara dirinya dengan berbagai perilaku. Intensi ialah faktor motivasional yang berpengaruh pada tingkah laku. Seberapa kuat kemauan seseorang untuk berusaha melakukan suatu tingkah laku tertentu dapat ditunjukkan oleh intensi. Intensi tersebut masih merupakan disposisi untuk bertingkah laku sampai ketika ada kesempatan yang tepat (Ajzen, 2005). Intensi dikembangkan dari hasil kegiatan yang akan menjadi penyebab untuk dipergunakan kembali dalam kegiatan yang sama tersebut (Ajzen, 2005). Menurut Ajzen, (2005), intensi merupakan pengaturan aktivitas yang ketika mendapatkan waktu dan kesempatan yang tepat maka akan terealisasi dengan bukti suatu tindakan. Intensi diasumsikan sebagai penangkap faktor motivasi yang memengaruhi perilaku, yaitu kemungkinan tentang seberapa keras seseorang ingin mencoba, seberapa banyak usaha yang telah dipikirkan, untuk melakukan perilaku tersebut. Jadi, intensi investasi merupakan minat seseorang yang apabila terdapat fator-faktor yang mendukung maka akan terealisasi dengan tindakan berinvestasi.

\section{Attitude toward Behavior}

Ajzen, (2005) menyatakan bahwa attitude toward behavior menggambarkan sikap terhadap perilaku yang ditentukan oleh keyakinan-keyakinan individu yang berhubungan dengan penilaian subjektif seseorang terhadap lingkungan sekitarnya. Mrngungkapkan kepercayaan dapat dilakukan melalui cara menghubungkan suatu perilaku yang akan kita prediksi dengan bermacam manfaat atau kerugian yang dapat diperoleh apabila kita melakukan atau tidak melakukan perilaku tersebut. Sikap terhadap perilaku 
Siti Mauidhoh Syarfi. Implementasi Theory of Planned Behavior dan Risk Tolerance terhadap Intensi Investasi Peer to Peer Lending

dapat diperkuat dengan keyakinan berdasar pada evaluasi dari data yang telah didapatkan bahwa dengan melakukan perilaku tersebut akan didapatkan keuntungan bagi pelakunya.

\section{Subjective Norm}

Norma subyektif merupakan perasaan atau dugaan-dugaan seseorang terhadap beberapa harapan dari orang-orang yang hadir di dalam kehidupannya mengenai dilakukan atau tidak dilakukannya sebuah perilaku. Keyakinan dapat memengaruhi norma subyektif, namun fungsi dari keyakinan tersebut didapatkan atas pandangan orang-orang lain yang memiliki hubungan dengannya (Mahyarni, 2013). Bhattacherjee, (2000), menyatakan bahwa pengaruh interpersonal dan eksternal berdampak pada norma subyektif. Teman, keluarga, kolega, dan individu yang memiliki pengalaman merupakan sumber dari pengaruh interpersonal. Sedangkan pihak luar organisasi yakni media masa, opini para ahli, dan informasi non personal merupakan sumber pengaruh eksternal yang dipertimbangkan individu dalam berperilaku.

\section{Perceived Behavioral Control}

Perceived behavioral control merupakan perasaan seseorang mengenai mudah atau sulitnya mewujudkan suatu perilaku tertentu. Keyakinan individu mengenai tersedianya sumber daya berupa peralatan, kompatibilitas, kompetensi, dan kesempatan yang mendukung atau menghambat perilaku yang akan diprediksi dan besarnya peran sumber daya tersebut merupakan penentu perceived behavioral control dalam mewujudkan perilaku tersebut (Ajzen, 2005).

\section{Risk Tolerance}

Risk tolerance dideskripsikan sebagai jumlah umum ketidakpastian seseorang yang mampu diterima saat membuat keputusan financial yang hampir menyentuh setiap bagian dari aktivitas sosial dan ekonomi (Putri, et al., 2017). Semakin tinggi tingkat risk tolerance seseorang maka semakin berani dalam mengambil keputusan. Risiko merupakan kemungkinan perbedaan antara return aktual dengan return yang diharapkan. Terdapat hubungan yang positif antara risiko dan return investasi. Sehingga, akan semakin besar risiko tersebut apabila kemungkinan perbedaannya juga semakin besar (Tandelilin, 2001). Arrow, (1971) menyatakan bahwa jika hal yang dipertaruhkan nilainya tidak besar maka seseorang cenderung mengabaikan risiko. Sebaliknya, bisa dipastikan setiap orang akan berusaha semaksimal mungkin untuk menekan risiko apabila hal yang dipertaruhkan bernilai besar. Tingkat risiko ini akan berpengaruh pada preferensi investor dalam berinvestasi, selain apakah investor tersebut termasuk risk taker atau risk averse.

\section{Hubungan antar Variabel}

Attitude toward behavior akan muncul ketika seseorang melakukan evaluasi individual mengenai keyakinannya terhadap hasil yang akan diterima dari perilaku berinvestasi sehingga memunculkan niat untuk berinvestasi. Attitude toward behavior berhubungan dengan emosi, afeksi dan kognisi kemudian menjadi evaluasi perasaan seseorang yang menempatkan pada keputusan menerima atau menolak investasi tersebut. Setelah itu akan terbentuk intensi/ minat untuk berinvestasi dan akan melakukan tindakan investasi tersebut apabila terdapat kesempatan dan waktu yang tepat (Ajzen, 2005).

H1: Terdapat pengaruh Attitude toward behavior terhadap Intensi Investasi masyarakat Surabaya pada peer to peer lending

Fishbein \& Ajzen, (1976) menjelaskan bahwa bagian terpenting dari norma subjektif yakni kekuatan sosial. Kekuatan sosial yang dimaksud berupa reward atau punishment yang diperoleh dari lingkungan sosial/ seseorang terhadap individu lainnya, rasa senang seseorang terhadap individu tersebut, seberapa besar dianggap sebagai seseorang yang berpengalaman serta kemauan dari individu tersebut. Seperti saat seseorang menyarankan kepada suatu individu untuk berinvestasi pada peer to peer lending maka individu tersebut akan cenderung memiliki intensi berinvestasi karena menghargai pendapat seseorang tersebut.

H2: Terdapat pengaruh subjective norm terhadap Intensi Investasi masyarakat Surabaya pada peer to peer lending 
Kontrol perilaku akan terwujud jika terdapat kesempatan dan terdapat faktor-faktor yang mendukung. Adanya faktor pendukung memberikan peran penting dalam hal perceived behavioral control. Hal tersebut juga berlaku pada sebaliknya, individu akan kesulitan untuk memahami perilaku yang dilakukanapabila faktor pendukung yang dirasakan juga semakin sedikit (Ajzen, 2005). Jadi, kontrol perilaku akan memunculkan niat berinvestasi apabila seseorang memiliki persepsi untuk mampu menghilangkan halangan/ hambatan berinvestasi melalui faktor-faktor pendukung (Ajzen, 2005).

H3: Terdapat pengaruh perceived behavioral control terhadap Intensi Investasi masyarakat Surabaya pada peer to peer lending

Budiarto \& Susanti, (2017) menjelaskan bahwa semakin tinggi tingkat risk tolerance seseorang maka semakin berani dalam mengambil keputusan. Maka pada saat investasi, seorang investor perlu membedakan antara tingkat pengembalian yang diharapkan dan tingkat pengembalian aktual yang diperoleh investor. Menurut Halim, (2005) investor dibedakan menjadi tiga apabila dikaitkan dengan preferensi pemilihan investor yaitu risk seeker, risk neutral, dan risk averse. Seseorang yang memiliki sifat berani mengambil risiko (risk seeker) akan memilih berinvestasi pada $P 2 P$ lending dengan tenor terlama dan pengembalian besar. Bagi seorang investor yang mempunyai sifat netral terhadap risiko (risk neutral) mungkin akan berinvestasi pada $P 2 P$ lending dengan tenor singkat dan pengembalian sesuai. Namun untuk investor yang menghindari risiko (risk averse), akan berpikir dua kali saat memutuskan tertarik atau tidak dengan peer to peer lending karena tidak adanya jaminan dari para borrower yang menggunakan dana mereka.

H4: Terdapat pengaruh risk tolerance terhadap Intensi Investasi masyarakat Surabaya pada peer to peer lending

\section{METODE PENELITIAN}

Dalam penelitian ini digunakan kategori penelitian konklusif kausalitas menggunakan data kuantitatif. Pengumpulan data dan informasi penelitian menggunakan sumber primer menggunakan kuesioner yang disebarkan secara online. Populasi penelitian yaitu masyarakat Kota Surabaya. Sampel yang digunakan dalam penelitian yakni sebanyak 200 angkatan kerja. Metode penarikan sampel yang digunakan yakni metode purposive sampling dengan pertimbangan yaitu masyarakat Kota Surabaya yang berstatus sebagai angkatan kerja di mana menurut BPS Jawa Timur angkatan kerja yakni penduduk usia kerja (15 tahun dan lebih) yang sedang bekerja, atau sedang mempunyai pekerjaan tetapi tidak bekerja sementara dan pengangguran kecuali pelajar/ dan mahasiswa serta mengurus rumah tangga dan dilanjutkan dengan memakai simple random sampling yakni mengambil sampel dilakukan secara arbitrer/ acak atau menyeluruh terhadap semua bagian wilayah Kota Surabaya dengan syarat memenuhi kriteria penduduk angkatan kerja.

Dalam penelitian ini digunakan metode analisis regresi linier berganda menggunakan program SPSS versi 23 yang bertujuan untuk memperlihatkan pengaruh variabel independen (attitude toward behavior, subjective norm, perceived behavioral control, dan risk tolerance) terhadap variabel dependen intensi investasi.

Teknik analisis yang dilakukan dalam penelitian diawali uji validitas dan reliabilitas yang digunakan untuk membuktikan bahwasannya kuesioner yang telah disusun akan terbukti dapat mengukur variabel penelitian dan diperoleh data yang konsisten. Kemudian dilakukan uji asumsi klasik yaitu (1) uji normalitas yang memiliki tujuan menguji apakah data residual berdistribusi normal dengan digunakannya grafik histogram, normal P-Plot, dan uji Kolmogorov-Smirnov, (2) uji multikolinieritas memiliki tujuan untuk menguji apakah terdapat korelasi antara variabel independen dengan dilihat nilai tolerance dan VIF, (3) uji heteroskedastisitas bertujuan menguji apakah terdapat perbedaan variance dan residual dari seiap pengamatan yang lain dengan uji gletser (Ghozali, 2016), (4) uji linieritas bertujuan untuk mengetahui apakah model empiris seharusnya linier, kuadrat, atau kubik dengan uji Lagrange Multiplier. Teknik analisis selanjutnya yaitu uji hipotesis berupa uji statistik kelayakan model 
Siti Mauidhoh Syarfi. Implementasi Theory of Planned Behavior dan Risk Tolerance terhadap Intensi Investasi Peer to Peer Lending

menggunakan uji $\mathrm{F}$, uji t digunakan pada pengukuran variabel individual, dan koefisien determinasi $\left(\mathrm{R}^{2}\right)$ agar dapat diketahui seberapa besar prosentase sumbangan variabel independen atas variabel dependen.

\section{HASIL DAN PEMBAHASAN}

Tabel 1.

\begin{tabular}{lcc}
\multicolumn{3}{c}{ KARAKTERISTIK RESPONDEN } \\
\hline \multicolumn{1}{c}{ Parameter } & Jumlah & $\%$ \\
\hline Jenis Kelamin & & \\
$\quad$ Perempuan & 134 & $67 \%$ \\
$\quad$ Laki-laki & 66 & $33 \%$ \\
Usia & & \\
$18-25$ & 167 & $83,5 \%$ \\
$26-35$ & 26 & $13 \%$ \\
$\quad 36-45$ & 7 & $3,5 \%$ \\
Pendidikan Terakhir & & \\
$\quad$ SMP/MTs & 1 & $0,5 \%$ \\
$\quad$ SMA/MA/SMK & 112 & $56 \%$ \\
$\quad$ Perguruan Tinggi & 87 & $43,5 \%$ \\
Tingkat Pendapatan & & \\
$\quad$ <1.000.000 & 78 & $39 \%$ \\
1.0000.001-1.500.000 & 17 & $8,5 \%$ \\
1.500.001-2.000.000 & 15 & $7,5 \%$ \\
$>2.000 .0001$ & 90 & $45 \%$ \\
\hline Sul
\end{tabular}

Sumber: data diolah.

Berdasarkan tabel 1, presentase tertinggi pada setiap karakteristik yakni perempuan untuk jenis kelamin, 18-25 tahun untuk karakteristik usia, perguruan tinggi untuk karakteristik pendidikan terakhir, dan > 2.000.000 untuk karakteristik tingkat pendapatan.

Berdasarkan tabel 2, uji SPSS untuk uji validitas dan reliabilitas dari 30 responden didapatkan bahwa item pertanyaan dari setiap variabel disebutkan valid sebab memperoleh nilai $r_{\text {hitung }}>r_{\text {tabel }}$, dan dikatakan valid karena diperoleh nilai cronbach's alpha >0,70 sehingga mampu digunakan sebagai alat penelitian.

Dari tabel 3, uji asumsi klasik untuk uji normalitas diperoleh hasil grafik histogram dan grafik P-Plot yang normal serta hasil uji Kolmogorov-Smirnov signifikansi 0,060 setelah dilakukan transformasi data. Untuk uji multikolinieritas didapatkan semua nilai tolerance dari setiap variabel independen $<10$ dan nilai VIF tidak ada yang bernilai melebihi 10. Untuk uji heteroskedastisitas didapatkan nilai glatser test dengan signifikansi melebihi 0,05. Dan dari uji linieritas didapatkan nilai uji Lagrange Multiplier dengan nilai $\mathrm{c}^{2}$ hitung $<\mathrm{c}^{2}$ tabel. Hasil uji asumsi klasik menyimpulkan bahwa penelitian dapat dilakukan sebab tidak terdapat penyimpangan data atau BLUE (Best Linear Unbiased Estimator). Untuk hasil uji regresi linier berganda didapatkan model regresi yang dapar dilihat di rumus (1).

$\mathrm{Y}=5,479+0,138 \mathrm{X}_{1}+0,214 \mathrm{X}_{4}+\mathrm{e}$

Hasil tersebut memperlihatkan bahwa variabel independen yang memiliki pengaruh siginifikan yakni variabel attitude toward behavior dan risk tolerance. Dari hasil statistik kelayakan model nilai signifikansi dari uji $\mathrm{F}$ yaitu 0,000 yang menunjukkan nilai kurang dari 0,05 sehingga didapatkan simpulan bahwa secara simultan intensi investasi dipengaruhi oleh variabel independen. Berdasarkan hasil uji t memperlihatkan bahwa variabel attitude toward behavior dan risk tolerance berpengaruh terhadap intensi investasi. Sedangkan variabel subjective norm dan perceived behavioral control tidak berpengaruh atas intensi investasi. 
Tabel 2.

HASIL UJI VALIDITAS DAN RELIABILITAS

\begin{tabular}{lllccc}
\hline & Item & rhitung & rtabel & Cronbach's Alpha & Cut of Value \\
\hline ATB & ATB1 & 0,857 & & & \\
& ATB2 & 0,873 & & & \\
& ATB3 & 0,868 & & & \\
& ATB2 & 0,781 & & & \\
& ATB5 & 0,732 & & & \\
& ATB6 & 0,789 & & & \\
SN & SN1 & 0,962 & & \\
& SN2 & 0,952 & 0,967 & \\
& SN3 & 0,982 & & & \\
PBC & PBC1 & 0,894 & & & \\
& PBC2 & 0,923 & & & \\
& PBC3 & 0,806 & & & \\
RT & RT1 & 0,885 & & & \\
& RT2 & 0,835 & & & \\
& RT3 & 0,840 & & & \\
II & II1 & 0,897 & & & \\
& II2 & 0,910 & & & \\
& II3 & 0,844 & & & \\
\hline
\end{tabular}

Sumber: Output SPSS (data diolah)

\section{Pengaruh Attitude toward Behavior terhadap Intensi Investasi}

Penelitian ini membuktikan bahwa variabel attitude toward behavior berpengaruh signifikan terhadap intensi investasi masyarakat Kota Surabaya pada peer to peer lending. Sehingga hasil membuktikan bahwa responden dalam penelitian telah menggunakan emosi, afeksi, dan kognisi yang timbul yang kemudian menempatkan responden pada keputusan untuk menerima investasi pada $P 2 P$ lending sehingga timbul dan terbentuk intensi investasi pada $P 2 P$ lending. Hasil penelitian mengindikasikan bahwa sebagian besar responden atau masyarakat Kota Surabaya yang berstatus sebagai responden penelitian memiliki intensi investasi pada $P 2 P$ lending dikarenakan proses investasi sangat mudah. Sehingga hasil penelitian ini memperlihatkan bahwa hipotesis diterima dan hasil tersebut sesuai dengan theory of planned behavior yang didalamnya dinyatakan bahwa niat seseorang untuk berperilaku didasari oleh beberapa faktor salah satunya yaitu attitude toward behavior (Ajzen, 1991). Hasil tersebut memperlihatkan bahwa responden menggunakan keyakinan subjektif terhadap dunia sekitarnya dan menghubungkannya dengan prilaku berinvestasi pada $P 2 P$ lending yakni tentang manfaat dan kerugian yang mungkin diperolehnya. Karena responden menggunakan emosi, afeksi, dan kognisinya saat melakukan evaluasi menganai $P 2 P$ lending dan berfikir bahwa melakukan investasi pada $P 2 P$ lending merupakan hal yang menguntungkan dengan proses yang mudah maka akan terbentuk intensi investasi pada $P 2 P$ lending dan akan melakukan tindakan investasi apabila terdapat kesempatan dan waktu yang tepat.

Hasil penelitian mengenai attitude toward behavior ini searah dengan penelitian Dewi, (2018) yang didalamnya dinyatakan bahwa attitude toward behavior berpengaruh positif terhadap intensi investasi dikarenakan responden dalam penelitian tersebut meyakini bahwa kegiatan investasi merupakan salah satu faktor yang dapat menciptakan inklusi keuangan di Indonesia. Hasil penelitian juga diperkuat oleh Phan \& Zhou, (2014); dan Raut et al., (2018) yang menyatakan bahwa secara positif attitude toward behavior berpengaruh terhadap intensi investasi sebab responden memiliki pemikiran yang terbuka dan meyakini akan kebaikan atau keuntungannya yang didapatkan dari kegiatan berinvestasi untuk masa depan. Hasil penelitian diperkuat dari hasil Rahmawati \& Maslichah, (2018) yang mengungkapkan bahwa attitude toward behavior berpengaruh secara positif terhadap intensi investasi dikarenakan keyakinan responden yang didasarkan pada tingkat pengetahuan yang ada pada diri mereka.

Tabel 3. 
Siti Mauidhoh Syarfi. Implementasi Theory of Planned Behavior dan Risk Tolerance terhadap Intensi Investasi Peer to Peer Lending

HASIL UJI ASUMSI KLASIK DAN UJI REGRESI

\begin{tabular}{|c|c|c|c|c|c|c|c|}
\hline Jenis & Tolerance & VIF & B & $\mathbf{t}$ & Sig. & $\mathbf{C}^{2}$ hitung & $C^{2}$ tabel \\
\hline Uji Normalitas & & & & &, 060 & & \\
\hline \multicolumn{8}{|c|}{ Uji Multikolinieritas } \\
\hline ATB & ,763 & 1,310 & & & & & \\
\hline SN & ,700 & 1,428 & & & & & \\
\hline $\mathrm{PBC}$ & 685 & 1,460 & & & & & \\
\hline RT & ,649 & 1,541 & & & & & \\
\hline \multicolumn{8}{|c|}{ Uji Heteroskedastisitas } \\
\hline ATB & & & & & ,202 & & \\
\hline $\mathrm{SN}$ & & & & & ,446 & & \\
\hline PBC & & & & & ,308 & & \\
\hline RT & & & & & ,056 & & \\
\hline Uji Linieritas & & & & & & 32,565 & 228,579 \\
\hline \multicolumn{8}{|c|}{ Uji Regresi Linier Berganda } \\
\hline (Constant) & & & 5,479 & 9,050 & ,000 & & \\
\hline ATB & & &, 138 & 3,571 & ,000 & & \\
\hline $\mathrm{SN}$ & & &,- 079 & $-1,570$ &, 118 & & \\
\hline PBC & & &,- 023 &,- 400 & ,690 & & \\
\hline RT & & &, 214 & 4,052 & ,000 & & \\
\hline Uji F & & & & & ,000 & & \\
\hline \multicolumn{8}{|l|}{ Uji t } \\
\hline ATB & & & & 3,571 &, 000 & & \\
\hline $\mathrm{SN}$ & & & & $-1,570$ &, 118 & & \\
\hline PBC & & & &,- 400 & 690 & & \\
\hline RT & & & & 4,052 &, 000 & & \\
\hline
\end{tabular}

Sumber: output SPSS (diolah penulis)

\section{Pengaruh Subjective Norm terhadap Intensi Investasi}

Penelitian ini membuktikan bahwa subjective norm tidak berpengaruh terhadap intensi investasi masyarakat Kota Surabaya pada $P 2 P$ lending. Hal tersebut dikarenakan responden penelitian tidak terpengaruh oleh dorongan dan kekuatan sosial yang timbul untuk menciptakan atau menolak intensi investasi pada $P 2 P$ lending. Alasan utama dikarenakan masih sebagian besar responden yang merasa kurang percaya terhadap dorongan sosial karena responden tergolong usia muda dan kurang dalam pengalaman berinvestasi sehingga responden merasa kurang percaya mengenai saran dari teman maupun lingkungan sosialnya. Sehingga hal ini memperlihatkan bahwa hipotesis ditolak dan hasil tersebut tidak sesuai dengan $T P B$ yang didalamnya dinyatakan bahwa niat individu untuk berperilaku didasari oleh beberapa faktor salah satunya yaitu subjective norm (Ajzen, 1991). Responden penelitian tidak terpengaruh oleh dorongan dan kekuatan sosialnya yakni responden tidak terpengaruh atas reward atau punishment yang disampaikan oleh lingkungan sosial terhadap dirinya. Tidak terdapat tekanan sosial yang didapatkan oleh responden atas saran dan sugesti lingkungannya. Sehingga ada ataupun tidaknya saran yang diberikan oleh sosial kepada dirinya tidak membuat responden memiliki intensi investasi terhadap $P 2 P$ lending sebab responden yang tergolong usia muda dan tidak begitu tertarik dengan persepsi sosial.

Hasil penelitian ini didukung oleh Rahmawati \& Maslichah, (2018) dengan hasil bahwa di antara subjective norm dan intensi investasi tidak terdapat pengaruh sebab keputusan yang diambil seseorang bisa berasal dari keyakinan atau pandangan seseorang terhadap sesuatu dan tidak selalu berdasarkan lingkungan sekitar. Hasil penelitian juga sejalan dengan Mahastanti \& Hariady, (2014) yang menyatakan bahwa di antara subjective norm dan intensi investasi tidak terdapat pengaruh sebab lingkungan responden meyakini bahwa investasi lebih dekat dengan perjudian dan dilarang oleh agama. 


\section{Pengaruh Perceived Behavioral Control terhadap Intensi Investasi}

Penelitian ini membuktikan bahwa bahwa perceived behavioral control tidak berpengaruh terhadap intensi investasi masyarakat Kota Surabaya pada $P 2 P$ lending. Dari hasil penelitian diperoleh bukti bahwa masih terdapat responden yang belum mendapatkan informasi yang jelas tentang $P 2 P$ lending. Alasan utama yaitu dikarenakan responden belum memperoleh informasi yang jelas tentang $P 2 P$ lending dan industri $P 2 P$ lending sendiri baru berkembang di Indonesia pada tahun 2016 yang tergolong jenis investasi baru. Responden juga berpikir kembali mengenai modal yang harus dikeluarkan dan juga keamanan dari $P 2 P$ lending. Hal tersebut juga memicu responden dalam memikirkan ulang mengenai keamanan pengembalian modal/ uang yang akan mereka gunakan untuk berinvestasi pada $P 2 P$ lending. Seperti yang telah diketahui bersama bahwa untuk berinvestasi pada $P 2 P$ lending hanya memerlukan proses melalui aplikasi online dan untuk menjadi peminjam tidak dibutuhkan jaminan/ agunan. Sehingga hal ini memperlihatkan bahwa hipotesis ditolak dan hasil tersebut tidak sesuai dengan $T P B$ yang didalamnya dinyatakan bahwa niat individu untuk berperilaku didasari oleh beberapa faktor salah satunya yaitu perceived behavioral control (Ajzen, 1991). Hal tersebut dikarenakan responden tidak memiliki persepsi untuk mampu dalam menghilangkan halangan/ hambatan untuk berinvestasi melalui faktor-faktor pendukung sehingga responden tidak dapat menciptakan intensi investasi terhadap $P 2 P$ lending sebab sebagian besar responden merupakan masyarakat berpenghasilan rendah dan uang merupakan salah satu faktor pendukung. Sesuai dengan $T P B$ yang menjelaskan apabila semakin sedikit faktor pendukung yang dirasakan oleh individu maka individu akan kesulitan memahami suatu perilaku (Ajzen, 2005).

Hasil penelitian ini mendukung penelitian Sondari \& Sudarsono, (2015) yang menyebutkan bahwa di antara perceived behavioral control dan intensi investasi tidak terdapat pengaruh sebab responden penelitian masih memikirkan tentang likuiditas dari jenis investasi.

\section{Pengaruh Risk Tolerance terhadap Intensi Investasi}

Penelitian ini membuktikan bahwa risk tolerance secara positif signifikan berpengaruh terhadap intensi investasi masyarakat Kota Surabaya pada peer to peer lending. Dari hasil penelitian diperoleh bahwa sebagian besar responden atau masyarakat Kota Surabaya yang berstatus sebagai responden penelitian memiliki sifat risk seeker terhadap intensi investasi pada $P 2 P$ lending. Responden yang bersifat risk seeker memungkinkan untuk memilih investasi pada $P 2 P$ lending dengan tenor terlama sekaligus pengembalian yang tinggi dan sesuai. Penelitian ini menunjukkan bahwa hipotesis diterima dan menunjukkan bahwa hasil tersebut sesuai dengan prospect theory yang didalamnya dinyatakan bahwa disaat seorang individu mengambil keputusan, dasar yang digunakan yakni keuntungan dan kerugian yang dihadapi, bukan berdasar pada total kekayaan (Kahneman \& Tversky, 1992). Juga selaras dengan teori tersebut bahwa individu memiliki respon yang berbeda atas keuntungan dan kerugian namun mereka mengambil keputusan tidak berdasarkan hasil akhir namun berdasarkan kondisi yang dihadapi setiap individu dan bagaimana kondisi tersebut dapat memengaruhi lingkungan sekitar pada saat penciptaan intensi. Hal tersebut dimungkinkan bahwa responden menambahkan faktor psikologi terhadap kondisi yang dihadapi pada saat penciptaan intensi investasi salah satu menurut teori in yakni decision frame. Framing bekerja melalui dua fase yakni fase pengeditan yakni individu akan mengidentifikasi semua kemungkinan apabila melakukan investasi dan memilah hal yang pasti serta beresiko. Fase kedua yakni evaluasi yang merupakan implementasi preferensi yang telah dibentuk dan pemilihan keputusan berdasarkan aspek manfaat berdasarkan masing-masing individu.

Hasil penelitian ini searah dengan Hilaliyah et al., (2019); Pradikasari \& Isbanah, (2018); dan Budiarto \& Susanti, (2017) yang didapatkan bahwa secara positif risk tolerance memengaruhi keputusan investasi sebab responden sesuai dengan karakteristik instrumen investasi penelitian yaitu high risk high return dan responden mempunyai tipe risk seeker untuk mendapatkan return yang tinggi pula.

\section{KESIMPULAN}

Berdasarkan hasil penelitian maka diperoleh simpulan yakni (1) Variabel attitude toward behavior berpengaruh terhadap intensi investasi masyarakat Kota Surabaya pada P2P lending dikarenakan 
Siti Mauidhoh Syarfi. Implementasi Theory of Planned Behavior dan Risk Tolerance terhadap Intensi Investasi Peer to Peer Lending

responden mempunyai keyakinan subjektif dan tercipta intensi investasi pada $P 2 P$ lending. (2) Variabel subjective norm tidak berpengaruh terhadap intensi investasi masyarakat Kota Surabaya pada peer to peer lending dikarenakan responden penelitian tidak terpengaruh oleh dorongan dan kekuatan sosial yang timbul untuk menciptakan atau menolak intensi investasi pada $P 2 P$ lending. (3) Variabel perceived behavioral control tidak berpengaruh terhadap intensi investasi masyarakat Kota Surabaya pada peer to peer lending dikarenakan responden tidak memiliki persepsi untuk mampu dalam menghilangkan halangan/ hambatan untuk berinvestasi melalui faktor-faktor pendukung sehingga responden tidak dapat menciptakan intensi investasi terhadap $P 2 P$ lending. (4) Variabel risk tolerance berpengaruh terhadap intensi investasi masyarakat Kota Surabaya pada peer to peer lending dikarenakan responden mempunyai ukuran risk tolerance yang tinggi atau risk seeker pada investasi $P 2 P$ lending dan terbentuk intensi investasi.

Harapan dari penelitian yakni dapat membantu investor khususnya masyarakat Kota Surabaya agar hendaknya lebih banyak berpikir ulang saat membentuk keyakinan diri atas penilaian subjektif terhadap $P 2 P$ lending serta memperhitungakan secara rasional tentang risiko atas keuntungan atau pengembalian yang akan didapatkan. Bagi Otoritas Jasa Keuangan diharapkan terus meningkatkan minat atau intensi investor terutama investasi jenis baru pada $P 2 P$ lending melalui upaya sosialisasi maupun himbauan tentang cara berinvestasi secara tepat. Keterbatasan penelitian yakni pada pengambilan sampel yang dilakukan dengaan cara penyebaran online sebab waktu dan tempat yang tidak memungkinkan sehingga peneliti kurang dalam mendapat informasi tambahan mengenai responden. Saran untuk peneliti selanjutnya hendaknya dapat menyempurnakan dengan menambahkan variabel-variabel lain yaitu financial literacy, overconvidence, regret aversion bias, excessive optimism, ilussion of control, dan self effifacy ketika menguji kembali mengenai intensi investasi sehingga dapat diperoleh gambaran atau hasil yang lebih akurat mengenai faktor yang mempengaruhi intensi investasi.

\section{DAFTAR PUSTAKA}

Ajzen, I. (1991). The theory of planned behavior. Organizational Behavior and Human Decision Processes, 50(2), 179-211. https://doi.org/10.1016

Ajzen, I. (2002). Perceived behavioral control, self-efficacy, locus of control, and the theory of planned behavior. Journal of Applied Social Psychology, 32(4), 665-683. https://doi.org/10.1111/j.15591816.2002.tb00236.x

Ajzen, I. (2005). Attitudes, Personality, and Behavior (2nd Editio). Retrieved from https://books.google.co.id/books?hl=id\&lr=\&id=dmJ9EGEy0ZYC\&oi=fnd\&pg=PP1\&dq=ajzen +2005\&ots=ECQOLiE05z\&sig=p34i4_fWFASk5gW71GdEUlxraZ4\&redir_esc=y\#v=onepage\& $\mathrm{q}=$ ajzen $2005 \& \mathrm{f}=$ false

Alleyne, P., \& Broome, T. (2011). Using the Theory of Planned Behaviour and Risk Propensity to Measure Investment Intentions Among Future Investors. Journal of Eastern Caribbean Studies, $36(1), 1-20$.

Annur, C. M. (2019). Berhenti Konsumtif, Milenial Didorong untuk Mulai Investasi. Retrieved November 1, 2019, from https://katadata-co-id.sdn.ampproject.org/

Aristanti, N. Des. (2019). Pengaruh Investasi Terhadap Pertumbuhan dan Pembangunan Ekonomi Indonesia. Retrieved September 20, 2011, from https://koinworks.com/

Arrow, K. J. (1992). Insurance, Risk and Resource Allocation. Huebner International Series on Risk, Insurance and Economic Security, 14. https://doi.org/10.1007/978-94-015-7957-5_11

Baghani, M., \& Sedaghat, P. (2014). Effect of Risk Perception and Risk Tolerance on Investors ' Decision Making in Tehran Stock Exchange. International Academic Journal of Accounting and Financial Management, 1(1), 79-87. 
Bhattacherjee, A. (2000). Acceptance of e-Commerce Services: The Case of Electronic Brokerages. Systems, Man and Cybernetics, Part A: IEE Transactions On Systems, Man, and Cybernetics, 30(4), 411-420. https://doi.org/1083-4427

Budiarto, A., \& Susanti. (2017). Pengaruh Financial Literacy, Overconvidence, Regret Aversion Bias, dan Risk Tolerance Terhadap Keputusan Investasi (Studi pada investor PT. Sucorinvest Central Gani Galeri Investasi BEI Universitas Negeri Surabaya). Jurnal Ilmu Manajemen, 05(02), 1-9.

Dayaratne, D. A. I., \& Wijethunga, A. W. G. C. N. (2015). Impact of psychology on behavioral intention in investing in capital markets: A survey of Colombo Stock Exchange. International Journal of Accounting \& Business Finance, (2), 37-45. Retrieved from http://www.jfn.ac.lk/maco/ijabf/?attachment_id=91

Deviyanti, L. P. A. E., Purnamawati, I. G. A., \& Yasa, I. N. P. (2017). Pengaruh Norma Subjektif, Persepsi Return dan Literasi Keuangan terhadap Minat Mahasiswa untuk Berinvestasi Saham di Pasar Modal. E-Journal S1 Ak Universitas Pendidikan Ganesha, 8(2). https://doi.org/10.23887/jimat.v8i2.14298

Dewi, I. G. A. A. P. (2018). Intensi Masyarakat Berinvestasi Pada Peer To Peer Lending: Analisis Theory of Planned Behavior. Jurnal Ilmiah Akuntansi \& Bisnis, 3(2), 118-132. https://doi.org/doi.org/10.24843/eja.2019.v26.i02.p20

Fahmi, I. (2012). Pengantar Pasar Modal. Bandung: Alfabeta.

Fishbein, M., \& Ajzen, I. (1976). Misconceptions about the Fishbein model: Reflections on a study by Songer-Nocks. Journal of Experimental Social Psychology, 12(6), 579-584. https://doi.org/10.1016/0022-1031(76)90036-6

Ghozali, I. (2016). Aplikasi Analisis Multivariate dengan Program IBM SPSS 21. Semarang: Badan Penerbit Universitas Diponegoro.

Halim, A. (2005). Analisis Investasi (Kedua). Jakarta: Salemba Empat.

Hikmah, Siagian, M., \& Siregar, P. (2020). Analisis Tingkat Literasi Keuangan, Experienced Regret, dan Risk Tolerance pada Keputusan Investasi di Batam. Jesya (Jurnal Ekonomi \& Ekonomi Syariah), 3(1), 138-146. https://doi.org/10.36778/jesya.v3i1.142

Hilaliyah, N., Susyanti, J., \& Wahono, B. (2019). Risk tolerance. Journal of Chemical Health and Safety, Vol. 23, p. 1. https://doi.org/10.1016/j.jchas.2016.09.002

Jajeli, R. (2018). Resmikan Pahlawan Ekonomi, Risma Ajak Warga Surabaya Jadi Pebisnis. Retrieved from htttps://m.detik.com/news/berita-jawa-timur/

JatimNewsroom. (2018). Sektor Koperasi dan UMKM di Jatim Terbukti Mampu Dorong Perekonomian. Retrieved November 2, 2019, from https://jatimprov.go.id/

Jayani, D. H. (2019). Fintech P2P Lending dan Pembayaran Tumbuh Paling Pesat. Retrieved October 15, 2019, from https://databoks.katadata.co.id/

Kahneman, D., \& Tversky, A. (1992). Kumulative Prospect Theory. Journal of Risk and Uncertainty, 35(6), 331-334. https://doi.org/10.15358/0340-1650-2006-6-331

Kominfo. (2019). UMKM Go Online, Upaya Wujudkan Visi “Digital Energy of Asia.” Retrieved from https://www.kominfo.go.id/content/detail/ 
Siti Mauidhoh Syarfi. Implementasi Theory of Planned Behavior dan Risk Tolerance terhadap Intensi Investasi Peer to Peer Lending

Luky, M. R. (2016). Minat Berinvestasi Di Pasar Modal: Aplikasi Theory Planned Behaviour Serta Persepsi Berinvestasi Di Kalangan Mahasiswa. Jurnal Ilmiah Mahasiswa FEB, 4(2), 53-62. https://doi.org/10.1007/s00132-012-1917-8

Mahastanti, L. A., \& Hariady, E. (2014). Determining the factors which affect the stock investment decisions of potential female investors in Indonesia. International Journal of Process Management and Benchmarking, 4(2), 186-197. https://doi.org/10.1504/IJPMB.2014.060407

Mahyarni. (2013). Theory of Reasoned Action dan Theory of Planned Behavior (Sebuah Kajian Historis tentang Perilaku). Jurnal El-Riyasah, 4(1), 13-23. https://doi.org/10.24014/jel.v4i1.17

OJK. (2019). Direktori Fintech per Juni 2019. Retrieved from https://www.ojk.go.id/id/kanal/iknb/data-dan-statistik/direktori/fintech/Pages/Direktori-Fintech(Peer-To-Peer-Lending)-per-Juni-2018.aspx

Paramita, R. S., Isbanah, Y., Kusumaningrum, T. M., Musdholifah, M., \& Hartono, U. (2018). Young investor behavior: implementation theory of planned behavior. International Journal of Civil Engineering and Technology, 9(7), 733-746.

Phan, C. K., \& Zhou, J. (2014). Factors Influencing Individual Investors' Behavior: An Empirical Study of the Vietnamese Stock Market. American Journal of Business and Management, 3(2), 77-94. https://doi.org/10.11634/216796061403527

Pradikasari, E., \& Isbanah, Y. (2018). Pengaruh financial literacy, illusion of control, overconfidence, risk tolerance, dan risk perception terhadap keputusan investasi pada mahasiswa di kota surabaya. Jurnal Ilmu Manajemen, 6, 424-434.

Putra, I. P. S., Ananingtiyas, H., Sari, D. R., Dewi, A. S., \& Silvy, M. (2016). experienced regret, dan risk tolerance pada pemilihan jenis investasi. Journal of Business and Banking, 5, 271-282. https://doi.org/10.14414/jbb.v5i2.548

Putri, F. K., Hakim, M. S., \& Bramanti, G. W. (2017). Pengaruh Faktor Kepribadian Terhadap Toleransi Risiko Keputusan Investasi Saham. Jurnal Seni Dan Sains ITS, 06. https://doi.org/10.12962/j23373520.v6i1.21318

Rahmawati, N., \& Maslichah. (2018). Minat Berinvestasi Di Pasar Modal: Aplikasi Theory Planned Behaviour Serta Persepsi Berinvestasi Di Kalangan Mahasiswa. Jurnal Ilmiah Riset Akuntansi, $07,41-54$.

Raut, R. K., Das, N., \& Kumar, R. (2018). Extending the theory of planned behaviour: Impact of past behavioural biases on the investment decision of Indian investors. Asian Journal of Business and Accounting, 11(1), 265-292. https://doi.org/10.22452/ajba.vol11no1.9

Seni, N. N. A., \& Ratnadi, N. M. D. (2017). Theory of Planned Behavior Untuk Memprediksi Niat Berinvestasi. E-Jurnal Ekonomi Dan Bisnis Universitas Udayana, 12, 4043. https://doi.org/10.24843/eeb.2017.v06.i12.p01

Sondari, C. M., \& Sudarsono, R. (2015). Using Theory of Planned Behavior in Predicting Intention to Invest : Case of Indonesia. International Academic Research Journal of Business and Technology, 137-141. https://doi.org/10.2991/gcbme-16.2016.118

Syarizka, D. (2019). Kontribusi UMKM terhadap PDB 2019 Doproyeksi Tumbuh 5\%. Retrieved September 20, 2011, from https://ekonomi.bisnis.com/

Tandelilin, E. (2001). Portofolio dan Investasi: Teori dan Aplikasi. Retrieved from 
https://books.google.co.id/books?id=YLORI8ul44kC\&pg=PT539\&dq=tandelilin+2001\&hl=id\& $\mathrm{sa}=\mathrm{X} \& \mathrm{ved}=0$ ahUKEwiPqren9NHIAhUW6XMBHbkwDDwQ6AEIKTAA\#v=onepage $\& \mathrm{q}=$ tande lilin $2001 \& \mathrm{f}=$ false

Tandio, T., \& Widanaputra, A. (2016). Pengaruh Pelatihan Pasar Modal, Return, Persepsi Risiko, Gender, Dan Kemajuan Teknologi Pada Minat Investasi Mahasiswa. E-Jurnal Akuntansi, 16(3), 2316-2341.

Taufiqoh, E., Diana, N., \& Junaidi. (2019). Pengaruh Norma Subjektif, Motivasi Investasi, Pengetahuan Investasi, Persepsi Return dan Literasi Keuangan Terhadap Minat Mahasiswa Berinvestasi Saham di Pasar Modal. Jurnal Ilmiah Riset Akuntansi, 08(01), 1-13.

Trenggana, A. F. M., \& Kuswardhana, R. (2017). Pengaruh Informasi Produk, Risiko Investasi, Kepuasaan Investor dan Minat Mahasiswa Berinvestasi. Jurnal Sekretaris \& Administrasi Bisnis, I(1), 8-17. https://doi.org/10.31104/jsab.v1i1.3

Walfajri, M. (2019). OJK Mensyaratkan Porsi Pinjaman ke UMKM 20\% untuk Memperoleh Izin Usaha P2P Lending. Retrieved September 20, 2011, from https://amp-kontan-co-id.cdn.ampproject.org/ 